\title{
The Role of the Thymus in Tolerance
}

\author{
Adam D. Griesemer ${ }^{1}$, Eric C. Sorenson ${ }^{1}$, and Mark A. Hardy ${ }^{1}$ \\ (1)Department of Surgery, Columbia University College of Physicians and Surgeons, 177 Fort \\ Washington Ave., Milstein Pavilion, 7 SK, New York, NY 10032, USA
}

\begin{abstract}
The thymus serves as the central organ of immunologic self-non-self discrimination. Thymocytes undergo both positive and negative selection resulting in $\mathrm{T}$ cells with a broad range of reactivity to foreign antigens but a lack of reactivity to self-antigens. The thymus is also the source of a subset of regulatory $\mathrm{T}$ cells that inhibit autoreactivity of $\mathrm{T}$ cell clones that may escape negative selection. As a result of these functions, the thymus has been shown to be essential for the induction of tolerance in many rodent and large animal models. Proper donor antigen presentation in the thymus following bone marrow, dendritic cell, or solid organ transplantation has been shown to induce tolerance to allografts. The molecular mechanisms of positive and negative selection and regulatory $\mathrm{T}$ cell development must be understood if a tolerance inducing therapeutic intervention is to be designed effectively. In this brief and selective review, we present some of the known information on $\mathrm{T}$ cell development and the role of the thymus on experimental models of transplant tolerance. We also cite some clinical attempts to induce tolerance to allografts using either pharmacologic or biologic interventions.
\end{abstract}

\section{Keywords}

Thymus; thymopoiesis; transplantation; tolerance; animal models

\section{Introduction}

In the healthy individual, self-non-self discrimination results in a balance between the extremes of immunodeficiency and autoimmunity. This balance represents a singular challenge: the $\mathrm{T}$ cell repertoire must respond to a seemingly limitless number of potential foreign antigens while simultaneously not responding to self-antigens expressed in all the various tissues. In order to achieve this, developing $\mathrm{T}$ lymphocytes undergo random rearrangement of specific regions of genes coding for their antigen receptors. During T cell development within the thymus, this process results in a small minority of immunologically useful prothymocytes with T cell receptors (TCRs) able to bind antigen-MHC complexes with appropriately low avidity initiating a positive selection pathway culminating in the survival of cells able to react against these antigens. Similarly, random rearrangement of TCR gene segments inevitably yields T cells that bind self-antigen with high avidity, and these potentially autoreactive lymphocytes are eliminated through negative selection

Address correspondence to: Mark A. Hardy, MD Department of Surgery, Columbia University College of Physicians and Surgeons 177 Fort Washington Ave., Milstein Pavilion, 7 SK New York, NY 10032, USA mah1@ columbia.edu.

This is a PDF file of an unedited manuscript that has been accepted for publication. As a service to our customers we are providing this early version of the manuscript. The manuscript will undergo copyediting, typesetting, and review of the resulting proof before it is published in its final citable form. Please note that during the production process errors may be discovered which could affect the content, and all legal disclaimers that apply to the journal pertain. 
mechanisms; if they remain the organism is faced with an autoimmune disease state where self-cells are destroyed.

Tolerance, or the state of immunologic non-responsiveness in the presence of a particular antigen, represents the self-discriminatory aspect of immunologic balance. Functional tolerance consists of two coordinated processes: 1 ) deletion of autoreactive lymphocytes during maturation in the central lymphoid organs before such cells reach maturity, and 2) functional suppression in the periphery of autoreactive lymphocytes that have escaped elimination. These two processes are referred to as central and peripheral tolerance. When this concept is applied to transplantation of tissues or organs, the ultimate aim is to delete donor specific alloreactive lymphocytes to avoid damage to a highly specific tissue or organ, without interfering with the rest of the homeostatic mechanisms. Central tolerance within the thymus classically refers to the scrutiny and negative selection of maturing thymocytes while the positive selection of regulatory $\mathrm{T}\left(\mathrm{T}_{\text {reg }}\right)$ lymphocytes, which modulate the peripheral immune response, also occurs within the thymus and thus may be considered a central tolerance mechanism. In order to design a tolerance induction protocol in patients, it is critical to briefly review the available information on the maintenance of self-recognition and reactivity to the non-self. We have organized this brief review with a focus on the known activities in the thymus and on the cell products that may be critical in both induction and maintenance of a specific unresponsive state.

\section{Early thymocyte maturation and positive selection}

Upon entering the thymus, immature lymphocytes originating in the bone marrow and committed to the thymocyte lineage undergo T-cell receptor (TCR) $\beta$ - and $\alpha$ - locus rearrangement (Figure 1). At this stage of development, T cells are characterized as $\mathrm{CD} 4^{+} / 8^{+}$ double-positive (DP), and the cells initiate expression of the $\alpha \beta$ TCR to a modest degree. The fate of each DP cell depends on the ability of its newly rearranged TCR to appropriately interact in a self-peptide-MHC complex; DP thymocytes are programmed to undergo apoptosis unless a 'rescue signal' is delivered via TCR: self-peptide-MHC ligation. During the three-day window prior to programmed cell death, sequential rounds of rearrangement at the TCR $\alpha$ locus, referred to as receptor editing, may increase the likelihood of successful self-MHC restriction (1-6). Ultimately, the vast majority (around 95\%) of DP cells fail to demonstrate any specificity for an MHC ligand, and these immunologically useless thymocytes undergo "death by neglect" or apoptosis $(7,8)$. A small proportion of DP cells express TCR that are able to bind an MHC ligand with mild avidity, and the resulting signaling cascade diverts those thymocytes from apoptosis (last minute reprieve) and induces DP maturation to the $\mathrm{CD}^{+} 8^{-}$or $\mathrm{CD}^{-} 8^{+}$single-positive (SP) stage(9). This type of positive selection signaling also triggers the expression of chemokines (traffic cop) that direct the $\mathrm{T}$ cell for further maturation within the thymic medulla(10-12). The identity and function of these chemokines and their receptors have been reviewed (13).

\section{Negative selection: Costimulation and the role of Fas}

Negative selection, also referred to as clonal deletion, is the process by which high-avidity TCR:self-peptide-MHC ligation induces cell death. Although distinction between lowavidity TCR binding (leading to positive selection) and high-avidity binding (leading to negative selection) is of critical importance, the mechanisms of this discrimination are not well understood. Negative selection was initially thought to coincide with positive selection within the thymic cortex. However, much of the early evidence for clonal deletion within the cortex is currently viewed as an artifact of experimental models(14-19). Although recent and more physiologically accurate models of clonal deletion demonstrate apoptosis following high-avidity TCR binding $(8,20,21)$, the bulk of negative selection for the remainder of self- 
reactive T-cells appears to occur within the medulla(8,22-24). Two mechanistic details arising from these models deserve specific mention: costimulation and the role of Fas. Exposure of DP thymocytes to anti-TCR mAb fails to induce significant apoptosis except in the presence of antigen-presenting cells (APCs)(17,25-27). The interaction between the thymocyte $\mathrm{CD} 28$ receptor and B7 APC ligand was subsequently identified as a crucial costimulatory factor $(28,29)$, and DP thymocytes were shown to undergo apoptosis in the combined presence of anti-TCR and anti-CD28 mAb in vitro(26,30). It is therefore not surprising that this interaction is of great interest in recent drug development. For the more mature SP thymocytes, mAb against the surface molecules CD5 and CD43 also independently provide sufficient costimulation to cause apoptosis in the presence of antiTCR mAb, suggesting a degree of costimulatory redundancy(30,31), which is a problem for the clinician when using only one agent for costimulatory blockade. When compared to the cortex, B7 expression is significantly higher in the medulla(32), thus suggesting the latter as the more favorable environment for negative selection(33) (Figure 1). The costimulatory molecules CD40, CD80, and CD86, which are expressed in the medulla by both medullary thymic epithelial cells (mTECs) and dendritic cells (DCs), have also been shown to have a role in clonal deletion $(34,35)$.

An important caveat to the costimulation requirement was discovered as semi-mature SP thymocytes were exposed to high-concentration of anti-TCR mAb: apoptosis was induced by the high-level TCR signaling in the absence of costimulation(30). In Fas ${ }^{-} l p r / l p r$ cells [reviewed in (36)], this effect is abrogated(17,26). Since Fas, a member of the TNF-receptor superfamily, contains a death domain and has been shown to play an important role in the physiologic regulation of cell death, this is somewhat surprising. It thus appears that apoptosis following moderate-avidity TCR binding requires costimulation and has been described as Fas-independent. With strong TCR ligation, apoptosis is Fas-dependent and proceeds in the absence of costimulation $(17,36)$. In that case the interaction of TCR receptor with its ligand leads to the formation of a death-inducing signaling (Fas-associated death domain protein - FADD) and the various caspases which lead to a caspase cascade and downstream apoptosis. Due to the lack of costimulatory APCs within the thymic cortex, it is likely that negative selection within the cortex is limited to high-intensity TCR signaling leading to priming of the cells for subsequent death on contact with APCs at the corticomedullary junction(37). Further mechanisms of the apoptotic sequence in clonal deletion are the subject of recent reviews $(38,39)$.

\section{Negative selection and tissue-specific antigens}

The successful elimination of potentially self-reactive thymocytes through clonal deletion requires a complete representation of self-antigens within the thymus. The comprehensive nature of antigen representation within the thymus was first noted with the discovery that genes for certain tissue specific antigens (TSAs), such as pancreatic proteins, are expressed ectopically (or 'promiscuously') in the thymic medulla(40-42) and the significance of this phenomenon was subsequently clarified and appreciated(42-45). Control of TSA expression appears to be partially controlled by the genes such as AIRE, whose deficiency in mice and even in man results in an autoimmune disorder (46-51). Current analyses suggest that mTECs express an excess of 500 to 1200 genes when compared with cTEC (cortical epithelial cells) controls(49); expression of representative genes has been observed for TSAs from every tissue in the body controlling the reactivity to self (52). Despite the surprisingly large extent of pGE within thymic mTECs, a number of proteins have been identified which are not expressed within the thymus, or are expressed at such low levels that they are not detected(44,52). Such proteins are often targets for autoimmunity(53). For example, the pancreatic protein GAD65 is expressed within the thymus at levels significantly lower than 
the related protein GAD67(54,55); corresponding antibody levels against GAD65 are significantly higher than GAD67 in type 1 diabetes mellitus patients(56).

\section{Antigen presentation and negative selection}

Effective negative selection requires the costimulatory support provided by APCs. (DCs constitutively express B7) (25,57-59). Accordingly, dendritic cells, which function in antigen cross-presentation within the medulla $(25,60,61)$, have been thought to play a major role in antigen presentation for negative selection. Indeed, studies demonstrated that DCs are indeed required for full tolerance induction (62-67). The results also show that in certain cases, however, mTECs may autonomously induce tolerance, particularly for $\mathrm{CD} 8^{+}$cells $(40,60-62,68,69)$. Strong agonist signaling from high-avidity TCR:self-peptide-MHC binding possibly plays a role in this process, which would be characterized as Fas-dependent and thus proceeds in the absence of costimulation $(39,60)$. The overall significance of mTEC-induced negative selection, however, is probably low.

Several studies have established dendritic cell acquisition of TSA from mTECs $(61,70-72)$. A number of mechanisms for this process have been proposed. First, as DCs efficiently phagocytize apoptotic cells, the frequent turnover of mature mTECs yields an abundance of TSA-rich cell fragments for DC processing and cross-presentation (73-76). Second, DCs may acquire protein material from living mTECs either via exosomes (77) or through an imprecisely characterized process of nibbling, whereby membrane-enclosed blebs of intracellular material are removed from living mTECs $(70-72,78,79)$. Finally, the observed transfer of intracellular material via gap junctions has been described as a method of antigen transfer (80).

\section{Dominant mechanisms of tolerance}

Despite the extensive mechanisms promoting negative selection of self-reactive thymocytes, autoreactive cells have been shown to regularly escape into the periphery (81-86). An additional critical function of the thymus is the selection of thymocytes responsible for antigen-specific tolerance regulation. The naturally occurring $\mathrm{CD} 4^{+} \mathrm{CD} 25^{+}$regulatory $\mathrm{T}$ $\left(\mathrm{T}_{\text {reg }}\right)$ lymphocyte subset is responsible for abolishing the response of autoreactive effector $\mathrm{T}$ cells for which negative selection mechanisms have failed (87), primarily by interrupting transcription of the $I L-2$ gene on effector thymocytes $(88,89)$. $T_{\text {reg }}$ cells express TCR with medium to high avidity for self-antigens (90-92), yet are diverted away from the negative selection pathway by an uncertain mechanism (93). Such non-deletional tolerance is also referred to as dominant, transferable, or infectious tolerance because $T_{\text {reg }}$ cells are able to induce tolerance to a corresponding foreign antigen after administration (passive transfer dependent on quantitative considerations) to naïve recipients. $\mathrm{T}_{\text {reg }}$ cells may also compensate for deficits in TSA expression within the thymus by attuning autoimmune responses in an antigen-nonspecific manner referred to as bystander suppression(94-97). These cells through cell-to-cell contact inhibit activation of naïve CD4+ T cells (98) and do not proliferate in response to antigens(99). This suppressor function can be eliminated by exposing Tregs to anti-CD3 and anti-CD28 mAbs(100) while IL2 is necessary for their activation (101) - both these findings may be important in development and selection of new immunosuppressive strategies.

A role for mTECs in $\mathrm{T}_{\text {reg }}$ development has been proposed $(90,91,102)$ since mTEC function may result in a reduced $\mathrm{T}_{\text {reg }}$ repertoire (103-105). Additionally, the FoxP3 family of transcription factors [reviewed in $(13,38,40,52)$ ], found primarily in $\mathrm{CD} 4{ }^{+} \mathrm{CD} 25^{+} \mathrm{T}_{\text {reg }}$ cells (at least in mice) and is found primarily in the thymic medulla. It appears now that FOXP3 acts a "master control gene" for the development and function of $\mathrm{T}_{\text {regs }}$ (96). The concept that $\mathrm{T}_{\text {regs }}$ that have the CD4+/CD25+/FoxP3+ phenotype are critical for maintenance of 
tolerance to both self and non-self antigens in rodents has been described by many investigators (87) (106). Although the finding of CD4+/CD25+/ FOXP3+ T cells supports the idea of tolerance induction and maintenance through formation of suppressor or regulatory cells, it still remains likely that other mechanisms of tolerance induction such as anergy or deletion are operating simultaneously or independent of the suppressor/regulatory pathways (107). Additionally, the finding in humans that some markers of $\mathrm{T}_{\text {regs }}$, such as FoxP3, CTLA4, and CD25 are shared by other T cells which represent a stage in the differentiation of activated $T$ cells complicates the analysis of the importance of $\mathrm{T}_{\text {regs }}$ in humans when evaluated by markers rather than by direct function (108) (109). It has also been suggested in studies of $\mathrm{T}_{\text {regs }}$ that CD25 represents a major marker of FoxP3 T cells with suppressive function (87) $(106,110)(111)$. This has raised the question at the clinical level of whether the use of anti-CD25 monoclonal antibodies, such as Daclizumab or Basiliximab, which are used as induction agents in organ transplantation, may interfere with the function or deplete $\mathrm{T}_{\text {regs }}$ in clinical situations. A recent study by our group in heart transplant recipients (112) has shown that the use of the anti-CD25 Daclizumab did not impair the development of $\mathrm{T}_{\text {regs }}$ in these patients and that there was a positive correlation between the serial presence of markers of $\mathrm{T}_{\text {regs }}$ and suppressor $\mathrm{T}$ cells (Ts) such as FoxP3, CTLA-4 and IL-10 in peripheral blood and the lack of rejection episodes.

As with effector $\mathrm{T}$ cell selection, evidence for the role of DCs in $\mathrm{T}_{\text {reg }}$ development has been recently described (113-116). A number of distinct populations of DCs exist within the thymus (117-119), and it is postulated that these subsets assume distinct tolerogenic roles, i.e. directing potentially self-reactive $\mathrm{T}$ cells to the $\mathrm{T}_{\text {reg }}$ lineage or to clonal deletion (120-122). Induced $\mathrm{T}_{\text {regs }}$ which are antigen-specific CD8+T suppressor cells (Ts) and $\mathrm{CD} 4+\mathrm{CD} 25+\mathrm{T}_{\text {regs }}$ can be generated by stimulation with immature myeloid DCs (imDC) or by mature plasmacytoid DCs (mpDC) (123). Human T cell clones produced in vivo or in vitro in the presence of IL-10 and imDCs inhibit antigen-induced activation of naïve T cells which can lead to experimental allograft acceptance in rodents (124) and in humans (125). Such CD4+CD25+ $\mathrm{T}_{\text {regs }}$ suppress normal $\mathrm{T}$ cell populations, making them anergic, and these cells in turn further suppress syngeneic CD4+ T cells via inhibitory cytokines (126). Suciu-Foca and her colleagues recently described another population of antigen-specific CD8+CD28 - T suppressor cells that express FoxP3 and act directly on professional antigen presenting cells (APCs), including imDCs to direct them towards tolerogenic state (127). On the basis of their studies, this group suggests that $\mathrm{T}$ cell suppression is induced by initial "tolerization" of APCs by CD8+ T cells which then induce anergic T helper cells that then acquire regulatory capacity as they increase FoxP3 expression and upregulate inhibitory receptors ILT3 and ILT4. Since DC's have a key role controlling the immune response and are also involved through costimulatory molecules and other factors in the maintenance of peripheral tolerance, it is not surprising that DC-based therapies for induction of immune regulation in autoimmunity and in tolerance are now of paramount interest. DCs express various receptors including at least one member of the inhibitory ILT family (immunoglobulin-like transcripts that contain a tyrosine-based inhibitory motif) and which are important in immuneregulation. One such receptor, ILT3, has been now shown to negatively regulate APC activation and its upregulation is required to induce CD4+Foxp3+ $\mathrm{T}_{\text {regs. }}$.

In vitro observations on intathymic DCs proposes that the $\mathrm{CD} 11 \mathrm{c}^{+} \mathrm{CD} 11 \mathrm{~b}^{-} \mathrm{DC}$ subset is activated by thymic stromal lymphopoietin (TSLP) from epithelial cells in Hassall's corpuscles (128) and that this subset subsequently compels $\mathrm{T}$ cells to the $\mathrm{T}_{\text {reg }}$ lineage $(113,129)$. This may also be accomplished by the expression of specific cytokines by dendritic cells and Hassall's corpuscles leading maturing SP cells toward $\mathrm{T}_{\text {reg }}$ development (130-134). $\mathrm{T}_{\text {reg }}$ cell development also requires costimulatory molecules CD28, CD80, and CD86, as well as CD40 and the CD40 ligand expressed by the medulla (135-137). This 
could therefore hinder the development of $\mathrm{T}_{\text {regs }}$ in protocols that rely on costimulatory blockade for tolerance induction. Finally, it should be noted that $\mathrm{T}$ differentiation is not limited to the thymic environment; mature, naïve $\mathrm{CD}_{4}^{+}$reg $\mathrm{T}$ cells can be induced in the periphery to develop into $\mathrm{CD} 4{ }^{+} \mathrm{CD} 25^{+} \mathrm{T}_{\text {reg }}$ cells (138-140).

\section{Thymus in experimental models of tolerance}

The report of successful tolerance induction by cotransplantation of donor bone marrow has brought us to the threshold of tolerance inducing protocols being used in the clinic (141). Given that the thymus is the origin of the self-non-self distinction, it is not surprising that it is integral in the experimental induction of tolerance to organ transplants. Even in experimental models using a mixed chimerism approach for tolerance induction, the presence of the thymus is required to maintain tolerance after the induction of chimerism(107). It also appears to be required for at least 3 weeks in the experimental models in rats using immature DC's (imDC) primed in vitro with immunodominant allopeptide where the DC's appear to re-circulate through the recipient thymus where they become "educated" (142). The subsequent development of CD4+CD25+FoxP3 anti-donor regulatory $\mathrm{T}$ cells is dependent on the presence of the thymus for at least 2-3 weeks after injection of the primed imDC and induction of tolerance to hearts, islets, or bone marrow is prevented by early thymectomy (143). Other studies in miniature swine have sought to determine reliable markers of successful tolerance induction following hematopoietic stem cell transplantation prior to transplantation of a solid organ. While peripheral T cell chimerism was not found to be entirely reliable(144), the presence of thymic chimerism and donor bone marrow engraftment correlated precisely with tolerance to subsequent solid organ transplants(145), suggesting that the thymus plays an active role in inducing and maintaining tolerance in hematopoietic cell transplant models.

Models of transplantation tolerance that do not rely on chimerism to induce tolerance have also demonstrated a dependency on the thymus for the induction of tolerance. In MGH miniature swine, class I mismatched renal transplants are uniformly accepted after a 12-day course of Cyclosporine(146). Mechanistic studies have shown that regulatory mechanisms are involved in mediating this tolerance (147-151). However, when the recipients were thymectomized 21 days prior to renal transplant, or when recipients were aged with involuted thymii, tolerance was not induced $(152,153)$. This finding has also been shown in other rodent models of tolerance $(154,155)$, suggesting that thymic-dependant tolerance strategies may be more successful in the pediatric population. We have also shown that inoculating the thymus directly with allopeptides or peptide pulsed self dendritic cells can induce tolerance to the dominant peptides and solid organ transplants(156-159). Together, these studies suggest that migration of donor antigen to an active thymus can induce transplantation tolerance in rodent and large animal models. Once central tolerance is induced experimentally, almost always in the presence of the thymus, the appearance and persistence of the regulatory mechanisms appears sufficient to maintain the state of donorspecific tolerance even when the thymus is ablated (usually 2- 3 weeks $(160,161)$ after tolerance induction to allow for initial "education" of T regs and prevention of subsequent generation of new alloreactive T cells. It must be mentioned that some models have demonstrated the ability to induce tolerance in thymectomized animals, likely by peripheral generation of Tregs, and this tolerance appears to be robust, again likely due to a lack of generation of new alloreactive T cells(162).

Another strategy for the induction of tolerance that has shown promise in animal models is the transplantation of allogeneic or xenogeneic thymus tissue. The transplantation of xenogenic thymus tissue to mice has been extensively studies by Sykes et al(163-169). These studies have shown that transplantation of porcine thymus tissue to mice leads to the 
development of donor-specific tolerance in vitro(168) and resulted in permanent donormatched porcine skin graft survival, while allogeneic murine skin was rejected(169). Studies by Yamada et al showed that if donor thymus was transplanted as a vascularized graft, tolerance could be induced across class I and full MHC mismatched barriers to renal and cardiac grafts(170-175). The development of the ability to transplant the thymus as a vascularized graft also allowed for studies to determine if a rejuvenated adult thymus could regain the ability to induce tolerance in the miniature swine model. When thymi from aged swine were transplanted to thymectomized juvenile recipients, they regained the architecture of a juvenile thymus and also the ability to facilitate the induction of tolerance to allogeneic renal grafts(176). This suggests that age related thymic involution can be reversed by a juvenile milieu. Multiple attempts to chemically rejuvenate the thymus have been attempted including administration of Il-7 $(177,178)$ and chemical castration via LH-RH antagonists(179). Using various fractions of the thymic hormone, thymosin(180), to initiate or to maintain the rejuvenation process has not been investigated and may offer a productive approach. The role of the thymus in T cell maturation may partially depend on its hormonal function and therefore its radioresistant reticuloepithelial scaffold(181). The latter plays an important function in the development of T cell ontogeny, not only in utero and infancy, but throughout the lifetime of the individual albeit at a reduced tempo(182). Since postnatal thymus tissue transplantation has been used successfully in juvenile patients with DiGeorge's syndrome(183-185) with in vitro evidence for tolerance to the donor thymus(186), it is reasonable to assume that clinical application of thymus transplantation for tolerance induction in the adult population would be possible if a reliable means of rejuvenating the adult donor thymus is found.

An alternative use of thymus transplantation could eventually lead to the induction of xenogeneic tolerance now that it has been demonstrated that transplantation of vascularized porcine thymus tissue to baboons was associated with in vitro evidence for donor-specific $\mathrm{T}$ cell unresponsiveness(187). When $\alpha 1,3$-galactosyltransferase knockout swine were used as the thymus and kidney donors, the recipients had survivals greater than 80 days with normal renal function, compared to recipients of kidneys alone who rejected their grafts in 30 days(188).

\section{Clinical Approaches to Induction of "Operational" Tolerance to Organ Transplantation}

It is at present still difficult to discuss tolerance induction in a clinical setting without the use of immunosuppressive agents. Many clinical studies have been conducted as part of this search for the "holy grail' and so far almost all have been unsuccessful. Clinicians have used various terms to define a "partial tolerance" where maintenance immunosuppression is minimized but not completely withdrawn. One such term has been "Operational Tolerance", while a more recent one has been "Prope Tolerance" coined by Sir Roy Calne (189).

One clinical approach that attempted to induce tolerance to renal allofgrafts consisted of using co-stimulation blockade with anti CTLA4-Ig antibody (Belatacept - Bristol Myers Squib) which offered sufficient experimental data in non-human primates to proceed with clinical trials (190). Initial Phase II studies reported by Vincenti et al (191) and a more recent report (192) of a Phase III multi-institutional trial involving more than 1000 patients randomized to receive an immunosuppressive regimen based on either Belatacept or cyclosporine showed that the incidence of patient and graft survival was similar and that the Belatacept group had significantly improved GFR (191). There has been no evidence that the Belatecept recipients were immunologically less responsive to their grafts than the control patients. 
The use of donor bone marrow infusion to induce tolerance was initially explored by Monaco and colleagues. Experimental models in rodents demonstrated that donor marrow infusion had a salutary effect on skin graft and islet transplant survival and tolerance induction. (193-195) Mechanistic studies performed in these models showed that allograft survival correlated with the presence of donor class II mRNA in the recipient's thymus (196). Studies in canines by the Monaco group demonstrated that donor bone marrow infusion induced prolonged graft survival in a large animal model(197). When this strategy was applied in a primate model using an anti-CD3 immunotoxin and donor bone marrow, prolonged graft survival was again observed(198). Small studies using donor bone marrow infusions were encouraging that this may be a useful adjunct to prolong graft survival and perhaps induce tolerance $(199,200)$. Attempts at clinical application of these important experimental and preliminary clinical findings have been made by the Pittsburgh group under the guidance of Dr. Thomas Starzl starting with the idea of inducing macrochimerism by injecting unmodified donor bone marrow along with the donor allograft. When these studies were repeated and expanded by Ciancio et al, it was found that acute rejection of cadaveric kidneys and the outcomes for recipients of living donors were no different in controls even when macrochimerism was detected in the recipients' bone marrow two years after transplantation (201). More importantly, no correlation has been found between the degree of microchimerism and renal allograft survival in several studies (202). Although the Pittsburgh Group initially postulated that any favorable effect of simultaneous donor bone marrow transplantation with the donor organ was due to development and persistence of microchimerism, the authors feel that it would be more likely that altered antigen presentation in the recipient's thymus by the APC's in the transplanted marrow may have a transient favorable effect on subsequent increase in the production of donor-specific regulatory $\mathrm{T}$ cells. Since the quantitative aspects of this manipulation appeared to be minimal relative to the existing $\mathrm{T}$ cell pool, the results of allograft prolongation remain controversial.

Intentional allograft tolerance with full withdrawal of maintenance immunosuppression has been demonstrated only by the Boston group, initially in two patients with multiple myeloma who required bone marrow transplantation and a renal allograft (203). Immunosuppression was discontinued after 73 and 77 days. Multilineage chimerism of $5-80 \%$ of CD3 cells was maintained for approximately 12 weeks and then declined to undetectable levels after 105-123 days while kidney function remained normal from day 3 to more than 2 and 4 years without any immunosuppression. Subsequently the same group transplanted 5 patients with combined bone marrow and kidney transplants from HLA single-haplotype mismatched living donors after non-myeoloablative conditioning. While one patient had irreversible humoral rejection, all immunosuppression could be discontinued in the 4 other patients 9 to 14 months after transplantation. Patients have continued to maintain stable renal function for 2 to 5.3 years. The $\mathrm{T}$ cells in these recipients were donor unresponsive in vitro while there were high levels of FoxP3 messenger RNA in graft biopsies (141). Although the Boston group did not achieve long term mixed chimerism (less than 3 weeks), they demonstrated durable renal allograft survival in 4 out of 5 patients. This finding is not surprising since induction of unresponsivness is not necessarily equivalent or may even not be related to maintenance of chimerism. It may, instead, depend heavily, if not exclusively, on appearance and maintenance of robust regulatory mechanisms; these may need to be periodically reinforced ("boosted").

The Stanford group has also attempted to use mixed chimerism to induce tolerance to renal allografts in 4 patients (204). Recipients conditioned with total-lymphoid irradiation (10 doses of $80 \mathrm{cGy}$ ) and given anti-thymocyte globulin and maintained on cyclosporine and prednisone received cytokine mobilized CD34+ hematopoetic progenitor cells from living donors. Three of these four recipients developed transient machrocimerism for up to 3 
months without evidence of graft-versus-host-disease(205). Two patients were weaned from immunosuppression but had to be restarted due to mild rejection episodes. A later report of 1 patient who was treated with a similar regimen with the addition of mycophenolate mofetil for 1 month after the administration of the cytokine mobilized CD34+ progenitor cells received an HLA matched kidney. Durable mixed chimreism was achieved and the patient had been off immunosuppression for 28 months without evidence of rejection (206). The mechanism responsible for tolerance in this patient remains to be elucidated.

The standard immunosuppression that is being used at present consists primarily of calcineurin inhibitors, cyclosporin or tacrolimus, both found to inhibit activated $\mathrm{T}$ cell proliferation, including Tregs, and in most experimental models tested found to inhibit experimental tolerance induction. Although tolerance has not been inhibited by calcineurin administration in the porcine model by Sachs et. al nor in humans subjected to tolerance induction by the Boston and Stanford groups, there is some evidence that cyclosporine inhibits AIRE expression and decreases the number of mTEC cells in mouse thymus(207). This might theoretically decrease the ability of thymus to perform appropriate negative selection that could lead to central tolerance. Other studies have shown a detrimental effect of cyclosporine on FoxP3 gene transcription(208) and Treg function in vivo(209).

Alternatively, the use of sirolimus has been found to promote the shift to Tregs in both experimental models $(210,211)$ and in man(210). Although the agent has not been very successful in promoting any type of clinical tolerance induction, it has that potential on the basis of several experimental studies in animals and in non-human primates(211).

We have tried to provide the reader with an overview of central tolerance, focusing initially on the mechanisms involved and then to very briefly summarize the existing clinical efforts in translating that knowledge to a clinical setting. To develop new strategies of selective immunosuppression it should be clear that much better understanding of the mechanisms of $\mathrm{T}$ cell inactivation remains to be translated to clinical usefulness for central tolerance induction in allograft recipients. A broader understanding of the induction and characterization of antigen-specific Tregs and Tsm, as well as mDCs and imDCs, involved in tolerance induction should lead to clinical protocols that will eventually "fool mother nature", allowing recipients to accept allogeneic, or even xenogeneic, transplants.

\section{Acknowledgments}

This work was supported in part by a grant from the National Institutes of Health: NIH T32 HL 007854-12

\section{References}

1. Petrie HT, Livak F, Schatz DG, Strasser A, Crispe IN, Shortman K. Multiple rearrangements in T cell receptor alpha chain genes maximize the production of useful thymocytes. J Exp Med. 1993; 178(2):615. [PubMed: 8393478]

2. McGargill MA, Derbinski JM, Hogquist KA. Receptor editing in developing T cells. Nat Immunol. 2000; 1(4):336. [PubMed: 11017106]

3. Wang F, Huang CY, Kanagawa O. Rapid deletion of rearranged T cell antigen receptor (TCR) Valpha-Jalpha segment by secondary rearrangement in the thymus: role of continuous rearrangement of TCR alpha chain gene and positive selection in the T cell repertoire formation. Proc Natl Acad Sci U S A. 1998; 95(20):11834. [PubMed: 9751751]

4. Huang CY, Sleckman BP, Kanagawa O. Revision of T cell receptor \{alpha\} chain genes is required for normal T lymphocyte development. Proc Natl Acad Sci U S A. 2005; 102(40):14356. [PubMed: 16186502]

5. Santori FR, Arsov I, Lilic M, Vukmanovic S. Editing autoreactive TCR enables efficient positive selection. J Immunol. 2002; 169(4):1729. [PubMed: 12165493]

Transplantation. Author manuscript; available in PMC 2011 September 15. 
6. Huang C, Kanagawa O. Ordered and coordinated rearrangement of the TCR alpha locus: role of secondary rearrangement in thymic selection. J Immunol. 2001; 166(4):2597. [PubMed: 11160321]

7. Egerton M, Scollay R, Shortman K. Kinetics of mature T-cell development in the thymus. Proc Natl Acad Sci U S A. 1990; 87(7):2579. [PubMed: 2138780]

8. Surh CD, Sprent J. T-cell apoptosis detected in situ during positive and negative selection in the thymus. Nature. 1994; 372(6501):100. [PubMed: 7969401]

9. Starr TK, Jameson SC, Hogquist KA. Positive and negative selection of T cells. Annu.Rev Immunol. 2003; 21:139. [PubMed: 12414722]

10. Ueno T, Saito F, Gray DH, et al. CCR7 signals are essential for cortex-medulla migration of developing thymocytes. J Exp Med. 2004; 200(4):493. [PubMed: 15302902]

11. Kwan J, Killeen N. CCR7 directs the migration of thymocytes into the thymic medulla. J Immunol. 2004; 172(7):3999. [PubMed: 15034011]

12. Misslitz A, Pabst O, Hintzen G, et al. Thymic T cell development and progenitor localization depend on CCR7. J Exp Med. 2004; 200(4):481. [PubMed: 15302903]

13. Takahama Y. Journey through the thymus: stromal guides for T-cell development and selection. Nat Rev Immunol. 2006; 6(2):127. [PubMed: 16491137]

14. von Boehmer H. Developmental biology of T cells in T cell-receptor transgenic mice. Annu Rev Immunol. 1990; 8:531. [PubMed: 2188673]

15. Murphy KM, Heimberger AB, Loh DY. Induction by antigen of intrathymic apoptosis of CD4+CD8+TCRlo thymocytes in vivo. Science. 1990; 250(4988):1720. [PubMed: 2125367]

16. Shi YF, Bissonnette RP, Parfrey N, Szalay M, Kubo RT, Green DR. In vivo administration of monoclonal antibodies to the CD3 T cell receptor complex induces cell death (apoptosis) in immature thymocytes. J Immunol. 1991; 146(10):3340. [PubMed: 1827483]

17. Kishimoto H, Sprent J. Negative selection in the thymus includes semimature T cells. J Exp Med. 1997; 185(2):263. [PubMed: 9016875]

18. Jondal M, Okret S, McConkey D. Killing of immature CD4+ CD8+ thymocytes in vivo by antiCD3 or 5'-(N-ethyl)-carboxamide adenosine is blocked by glucocorticoid receptor antagonist RU-486. Eur J Immunol. 1993; 23(6):1246. [PubMed: 8099013]

19. Martin S, Bevan MJ. Antigen-specific and nonspecific deletion of immature cortical thymocytes caused by antigen injection. Eur J Immunol. 1997; 27(10):2726. [PubMed: 9368633]

20. Baldwin KK, Trenchak BP, Altman JD, Davis MM. Negative selection of T cells occurs throughout thymic development. J Immunol. 1999; 163(2):689. [PubMed: 10395659]

21. Goldman KP, Park CS, Kim M, Matzinger P, Anderson CC. Thymic cortical epithelium induces self tolerance. Eur J Immunol. 2005; 35(3):709. [PubMed: 15719367]

22. Sant'Angelo DB, Janeway CA Jr. Negative selection of thymocytes expressing the D10 TCR. Proc Natl Acad Sci U S A. 2002; 99(10):6931. [PubMed: 12011450]

23. Baldwin TA, Sandau MM, Jameson SC, Hogquist KA. The timing of TCR alpha expression critically influences T cell development and selection. J Exp Med. 2005; 202(1):111. [PubMed: 15998791]

24. Zhan Y, Purton JF, Godfrey DI, Cole TJ, Heath WR, Lew AM. Without peripheral interference, thymic deletion is mediated in a cohort of double-positive cells without classical activation. Proc Natl Acad Sci U S A. 2003; 100(3):1197. [PubMed: 12538873]

25. Matzinger P, Guerder S. Does T-cell tolerance require a dedicated antigen-presenting cell? Nature. 1989; 338(6210):74. [PubMed: 2783992]

26. Punt JA, Osborne BA, Takahama Y, Sharrow SO, Singer A. Negative selection of CD4 + CD8 + thymocytes by $\mathrm{T}$ cell receptor-induced apoptosis requires a costimulatory signal that can be provided by CD28. Journal of Experimental Medicine. 1994; 179:709. [PubMed: 8294878]

27. Page DM, Kane LP, Allison JP, Hedrick SM. Two signals are required for negative selection of CD4+CD8+ thymocytes. J Immunol. 1993; 151(4):1868. [PubMed: 7688388]

28. Buhlmann JE, Elkin SK, Sharpe AH. A role for the B7-1/B7-2:CD28/CTLA-4 pathway during negative selection. J Immunol. 2003; 170(11):5421. [PubMed: 12759417]

29. Gao JX, Zhang H, Bai XF, et al. Perinatal blockade of b7-1 and b7-2 inhibits clonal deletion of highly pathogenic autoreactive T cells. J Exp Med. 2002; 195(8):959. [PubMed: 11956287]

Transplantation. Author manuscript; available in PMC 2011 September 15. 
30. Kishimoto H, Sprent J. Several different cell surface molecules control negative selection of medullary thymocytes. J Exp Med. 1999; 190(1):65. [PubMed: 10429671]

31. Page DM. Cutting edge: thymic selection and autoreactivity are regulated by multiple coreceptors involved in T cell activation. J Immunol. 1999; 163(7):3577. [PubMed: 10490949]

32. Sprent J. Central tolerance of T cells. Int Rev Immunol. 1995; 13(2):95. [PubMed: 8789423]

33. Lo D, Reilly CR, Burkly LC, Dekoning J, Laufer TM, Glimcher LH. Thymic stromal cell specialization and the T-cell receptor repertoire. Immunol Res. 1997; 16(1):3. [PubMed: 9048205]

34. Foy TM, Page DM, Waldschmidt TJ, et al. An essential role for gp39, the ligand for CD40, in thymic selection. J Exp Med. 1995; 182(5):1377. [PubMed: 7595208]

35. Page DM, Roberts EM, Peschon JJ, Hedrick SM. TNF receptor-deficient mice reveal striking differences between several models of thymocyte negative selection. J Immunol. 1998; 160(1): 120. [PubMed: 9551964]

36. Kishimoto H, Surh CD, Sprent J. A role for Fas in negative selection of thymocytes in vivo. J Exp Med. 1998; 187(9):1427. [PubMed: 9565635]

37. Punt JA, Havran W, Abe R, Sarin A, Singer A. T cell receptor (TCR)-induced death of immature CD4+CD8+ thymocytes by two distinct mechanisms differing in their requirement for CD28 costimulation: implications for negative selection in the thymus. J Exp Med. 1997; 186(11):1911. [PubMed: 9382889]

38. Sigal LH. Basic science for the clinician 37: Protecting against autoimmunity-tolerance: mechanisms of negative selection in the thymus. J Clin Rheumatol. 2006; 12(2):99. [PubMed: 16601548]

39. Palmer E. Negative selection--clearing out the bad apples from the T-cell repertoire. Nat Rev Immunol. 2003; 3(5):383. [PubMed: 12766760]

40. Smith KM, Olson DC, Hirose R, Hanahan D. Pancreatic gene expression in rare cells of thymic medulla: evidence for functional contribution to T cell tolerance. Int Immunol. 1997; 9(9):1355. [PubMed: 9310839]

41. Kyewski B, Klein L. A central role for central tolerance. Annu Rev Immunol. 2006; 24:571. [PubMed: 16551260]

42. Derbinski J, Schulte A, Kyewski B, Klein L. Promiscuous gene expression in medullary thymic epithelial cells mirrors the peripheral self. Nat Immunol. 2001; 2(11):1032. [PubMed: 11600886]

43. Kyewski B, Derbinski J, Gotter J, Klein L. Promiscuous gene expression and central T-cell tolerance: more than meets the eye. Trends Immunol. 2002; 23(7):364. [PubMed: 12103357]

44. Gotter J, Brors B, Hergenhahn M, Kyewski B. Medullary epithelial cells of the human thymus express a highly diverse selection of tissue-specific genes colocalized in chromosomal clusters. J Exp Med. 2004; 199(2):155. [PubMed: 14734521]

45. Sospedra M, Ferrer-Francesch X, Dominguez O, Juan M, Foz-Sala M, Pujol-Borrell R. Transcription of a broad range of self-antigens in human thymus suggests a role for central mechanisms in tolerance toward peripheral antigens. J Immunol. 1998; 161(11):5918. [PubMed: 9834072]

46. Pitkanen J, Peterson P. Autoimmune regulator: from loss of function to autoimmunity. Genes Immun. 2003; 4(1):12. [PubMed: 12595897]

47. Nagamine K, Peterson P, Scott HS, et al. Positional cloning of the APECED gene. Nat Genet. 1997; 17(4):393. [PubMed: 9398839]

48. Vogel A, Strassburg CP, Obermayer-Straub P, Brabant G, Manns MP. The genetic background of autoimmune polyendocrinopathy-candidiasis-ectodermal dystrophy and its autoimmune disease components. J Mol Med. 2002; 80(4):201. [PubMed: 11976729]

49. Derbinski J, Gabler J, Brors B, et al. Promiscuous gene expression in thymic epithelial cells is regulated at multiple levels. J Exp Med. 2005; 202(1):33. [PubMed: 15983066]

50. Anderson MS, Venanzi ES, Klein L, et al. Projection of an immunological self shadow within the thymus by the aire protein. Science. 2002; 298(5597):1395. [PubMed: 12376594]

51. Kuroda N, Mitani T, Takeda N, et al. Development of autoimmunity against transcriptionally unrepressed target antigen in the thymus of Aire-deficient mice. J Immunol. 2005; 174(4):1862. [PubMed: 15699112]

Transplantation. Author manuscript; available in PMC 2011 September 15. 
52. Kyewski B, Derbinski J. Self-representation in the thymus: an extended view. Nat Rev Immunol. 2004; 4(9):688. [PubMed: 15343368]

53. Klein L, Klugmann M, Nave KA, Tuohy VK, Kyewski B. Shaping of the autoreactive T-cell repertoire by a splice variant of self protein expressed in thymic epithelial cells. Nat Med. 2000; 6(1):56. [PubMed: 10613824]

54. Viglietta V, Kent SC, Orban T, Hafler DA. GAD65-reactive T cells are activated in patients with autoimmune type 1a diabetes. J Clin Invest. 2002; 109(7):895. [PubMed: 11927616]

55. Lernmark A. Controlling the controls: GAD65 autoreactive T cells in type 1 diabetes. J Clin Invest. 2002; 109(7):869. [PubMed: 11927613]

56. Baekkeskov S, Kanaani J, Jaume JC, Kash S. Does GAD have a unique role in triggering IDDM? J Autoimmun. 2000; 15(3):279. [PubMed: 11040068]

57. Mazda O, Watanabe Y, Gyotoku J, Katsura Y. Requirement of dendritic cells and B cells in the clonal deletion of Mls-reactive T cells in the thymus. J Exp Med. 1991; 173(3):539. [PubMed: 1900074]

58. Liu Y, Jones B, Brady W, Janeway CA Jr. Linsley PS. Co-stimulation of murine CD4 T cell growth: cooperation between B7 and heat-stable antigen. Eur J Immunol. 1992; 22(11):2855. [PubMed: 1385153]

59. Larsen CP, Ritchie SC, Pearson TC, Linsley PS, Lowry RP. Functional expression of the costimulatory molecule, B7/BB1, on murine dendritic cell populations. J Exp Med. 1992; 176(4): 1215. [PubMed: 1328465]

60. Gallegos AM, Bevan MJ. Central tolerance: good but imperfect. Immunol Rev. 2006; 209:290. [PubMed: 16448550]

61. Dillon SR, Jameson SC, Fink PJ. V beta 5+ T cell receptors skew toward OVA+H-2Kb recognition. J Immunol. 1994; 152(4):1790. [PubMed: 8120388]

62. Gallegos AM, Bevan MJ. Central tolerance to tissue-specific antigens mediated by direct and indirect antigen presentation. J Exp Med. 2004; 200(8):1039. [PubMed: 15492126]

63. Gao EK, Lo D, Sprent J. Strong T cell tolerance in parent-->F 1 bone marrow chimeras prepared with supralethal irradiation. Evidence for clonal deletion and anergy. Journal of Experimental Medicine. 1990; 171:1101.

64. Sprent J, Kosaka H, Gao EK. T cell tolerance after bone marrow transplantation in mice. Bone Marrow Transplant. 1992; 10(Suppl 1):5. [PubMed: 1521090]

65. Webb SR, Sprent J. Tolerogenicity of thymic epithelium. Eur J Immunol. 1990; 20(11):2525. [PubMed: 2123795]

66. van Meerwijk JP, MacDonald HR. In vivo T-lymphocyte tolerance in the absence of thymic clonal deletion mediated by hematopoietic cells. Blood. 1999; 93(11):3856. [PubMed: 10339493]

67. van Meerwijk JP, Marguerat S, Lees RK, Germain RN, Fowlkes BJ, MacDonald HR. Quantitative impact of thymic clonal deletion on the T cell repertoire. J Exp Med. 1997; 185(3):377. [PubMed: 9053438]

68. Klein L, Roettinger B, Kyewski B. Sampling of complementing self-antigen pools by thymic stromal cells maximizes the scope of central T cell tolerance. Eur J Immunol. 2001; 31(8):2476. [PubMed: 11500832]

69. Merkenschlager M, Benoist C, Mathis D. Evidence for a single-niche model of positive selection. Proc Natl Acad Sci U S A. 1994; 91(24):11694. [PubMed: 7972126]

70. Humblet C, Rudensky A, Kyewski B. Presentation and intercellular transfer of self antigen within the thymic microenvironment: expression of the $\mathrm{E}$ alpha peptide-I-Ab complex by isolated thymic stromal cells. Int Immunol. 1994; 6(12):1949. [PubMed: 7696212]

71. Barlow AK, He X, Janeway C Jr. Exogenously provided peptides of a self-antigen can be processed into forms that are recognized by self-T cells. J Exp Med. 1998; 187(9):1403. [PubMed: 9565633]

72. Viret C, Barlow AK, Janeway CA Jr. On the intrathymic intercellular transfer of self-determinants. Immunol Today. 1999; 20(1):8. [PubMed: 10081222]

73. Boehm T, Scheu S, Pfeffer K, Bleul CC. Thymic medullary epithelial cell differentiation, thymocyte emigration, and the control of autoimmunity require lympho-epithelial cross talk via LTbetaR. J Exp Med. 2003; 198(5):757. [PubMed: 12953095]

Transplantation. Author manuscript; available in PMC 2011 September 15. 
74. Albert ML, Sauter B, Bhardwaj N. Dendritic cells acquire antigen from apoptotic cells and induce class I-restricted CTLs. Nature. 1998; 392(6671):86. [PubMed: 9510252]

75. Albert ML, Pearce SF, Francisco LM, et al. Immature dendritic cells phagocytose apoptotic cells via alphavbeta5 and CD36, and cross-present antigens to cytotoxic T lymphocytes. Journal of Experimental Medicine. 1998; 188(7):1359. [PubMed: 9763615]

76. Bellone M, Iezzi G, Rovere P, et al. Processing of engulfed apoptotic bodies yields T cell epitopes. J Immunol. 1997; 159(11):5391. [PubMed: 9548479]

77. Thery C, Zitvogel L, Amigorena S. Exosomes: composition, biogenesis and function. Nat Rev Immunol. 2002; 2(8):569. [PubMed: 12154376]

78. Harshyne LA, Zimmer MI, Watkins SC, Barratt-Boyes SM. A role for class A scavenger receptor in dendritic cell nibbling from live cells. J Immunol. 2003; 170(5):2302. [PubMed: 12594251]

79. Harshyne LA, Watkins SC, Gambotto A, Barratt-Boyes SM. Dendritic cells acquire antigens from live cells for cross-presentation to CTL. J Immunol. 2001; 166(6):3717. [PubMed: 11238612]

80. Neijssen J, Herberts C, Drijfhout JW, Reits E, Janssen L, Neefjes J. Cross-presentation by intercellular peptide transfer through gap junctions. Nature. 2005; 434(7029):83. [PubMed: 15744304]

81. Schluesener HJ, Wekerle H. Autoaggressive T lymphocyte lines recognizing the encephalitogenic region of myelin basic protein: in vitro selection from unprimed rat $\mathrm{T}$ lymphocyte populations. $\mathrm{J}$ Immunol. 1985; 135(5):3128. [PubMed: 2413113]

82. Fowell D, Mason D. Evidence that the T cell repertoire of normal rats contains cells with the potential to cause diabetes. Characterization of the CD4+ T cell subset that inhibits this autoimmune potential. J Exp Med. 1993; 177(3):627. [PubMed: 8094734]

83. Wucherpfennig KW, Zhang J, Witek C, et al. Clonal expansion and persistence of human T cells specific for an immunodominant myelin basic protein peptide. J Immunol. 1994; 152(11):5581. [PubMed: 7514641]

84. Liblau R, Tournier-Lasserve E, Maciazek J, et al. T cell response to myelin basic protein epitopes in multiple sclerosis patients and healthy subjects. Eur J Immunol. 1991; 21(6):1391. [PubMed: 1710565]

85. Sun JB, Olsson T, Wang WZ, et al. Autoreactive T and B cells responding to myelin proteolipid protein in multiple sclerosis and controls. Eur J Immunol. 1991; 21(6):1461. [PubMed: 1710567]

86. Bouneaud C, Kourilsky P, Bousso P. Impact of negative selection on the T cell repertoire reactive to a self-peptide: a large fraction of T cell clones escapes clonal deletion. Immunity. 2000; 13(6): 829. [PubMed: 11163198]

87. Sakaguchi S. Naturally arising CD4+ regulatory t cells for immunologic self-tolerance and negative control of immune responses. Annu.Rev Immunol. 2004; 22:531. [PubMed: 15032588]

88. Sakaguchi S, Sakaguchi N, Shimizu J, et al. Immunologic tolerance maintained by CD25+ CD4+ regulatory T cells: their common role in controlling autoimmunity, tumor immunity, and transplantation tolerance. Immunol Rev. 2001; 182:18-32. 18. [PubMed: 11722621]

89. Shevach EM, McHugh RS, Piccirillo CA, Thornton AM. Control of T-cell activation by CD4+ CD25+ suppressor T cells. Immunological Reviews. 2001; 182:58. [PubMed: 11722623]

90. Jordan MS, Boesteanu A, Reed AJ, et al. Thymic selection of CD4+CD25+ regulatory T cells induced by an agonist self-peptide. Nat Immunol. 2001; 2(4):301. [PubMed: 11276200]

91. Apostolou I, Sarukhan A, Klein L, von Boehmer H. Origin of regulatory T cells with known specificity for antigen. Nat Immunol. 2002; 3(8):756. [PubMed: 12089509]

92. Hsieh CS, Liang Y, Tyznik AJ, Self SG, Liggitt D, Rudensky AY. Recognition of the peripheral self by naturally arising CD25+ CD4+ T cell receptors. Immunity. 2004; 21(2):267. [PubMed: 15308106]

93. Pacholczyk R, Kraj P, Ignatowicz L. Peptide specificity of thymic selection of CD4+CD25+ T cells. Journal of Immunology. 2002; 168(2):613.

94. Modigliani Y, Bandeira A, Coutinho A. A model for developmentally acquired thymus-dependent tolerance to central and peripheral antigens. Immunol Rev. 1996; 149:155. [PubMed: 9005213]

95. Waldmann H, Cobbold S. Regulating the immune response to transplants. a role for CD4+ regulatory cells? Immunity. 2001; 14(4):399. [PubMed: 11336685]

Transplantation. Author manuscript; available in PMC 2011 September 15. 
96. Hori S, Nomura T, Sakaguchi S. Control of regulatory T cell development by the transcription factor Foxp3. Science. 2003; 299(5609):1057. [PubMed: 12522256]

97. Thornton AM, Shevach EM. Suppressor effector function of CD4+CD25+ immunoregulatory T cells is antigen nonspecific. Journal of Immunology. 2000; 164(1):183.

98. Shevach EM. Regulatory T cells in autoimmmunity*. Annu.Rev.Immunol. 2000; 18:423. [PubMed: 10837065]

99. Sutmuller RP, Offringa R, Melief CJ. Revival of the regulatory T cell: new targets for drug development. Drug Discov Today. 2004; 9(7):310. [PubMed: 15037230]

100. Fu S, Zhang N, Yopp AC, et al. TGF-beta induces Foxp3 + T-regulatory cells from CD4 + C. Am J Transplant. 2004; 4(10):1614. [PubMed: 15367216]

101. Thornton AM, Donovan EE, Piccirillo CA, Shevach EM. Cutting edge: IL-2 is critically required for the in vitro activation of CD4+CD25+ T cell suppressor function. J Immunol. 2004; 172(11): 6519. [PubMed: 15153463]

102. Seddon B, Mason D. The third function of the thymus. Immunol Today. 2000; 21(2):95. [PubMed: 10652468]

103. Derbinski J, Kyewski B. Linking signalling pathways, thymic stroma integrity and autoimmunity. Trends Immunol. 2005; 26(10):503. [PubMed: 16039157]

104. Akiyama T, Maeda S, Yamane S, et al. Dependence of self-tolerance on TRAF6-directed development of thymic stroma. Science. 2005; 308(5719):248. [PubMed: 15705807]

105. Kajiura F, Sun S, Nomura T, et al. NF-kappa B-inducing kinase establishes self-tolerance in a thymic stroma-dependent manner. J Immunol. 2004; 172(4):2067. [PubMed: 14764671]

106. Shevach EM. CD4+ CD25+ suppressor T cells: more questions than answers. Nat Rev Immunol. 2002; 2(6):389. [PubMed: 12093005]

107. Khan A, Tomita Y, Sykes M. Thymic dependence of loss of tolerance in mixed allogeneic bone marrow chimeras after depletion of donor antigen. Transplantation. 1996; 62:380. [PubMed: 8779687]

108. Pillai V, Ortega SB, Wang CK, Karandikar NJ. Transient regulatory T-cells: a state attained by all activated human T-cells. Clin Immunol. 2007; 123(1):18. [PubMed: 17185041]

109. Wang J, Ioan-Facsinay A, van der Voort EI, Huizinga TW, Toes RE. Transient expression of FOXP3 in human activated nonregulatory CD4+ T cells. Eur J Immunol. 2007; 37(1):129. [PubMed: 17154262]

110. Bluestone JA, Abbas AK. Natural versus adaptive regulatory T cells. Nat Rev Immunol. 2003; 3(3):253. [PubMed: 12658273]

111. Vlad G, Cortesini R, Suciu-Foca N. License to heal: bidirectional interaction of antigen-specific regulatory T cells and tolerogenic APC. J Immunol. 2005; 174(10):5907. [PubMed: 15879080]

112. Vlad G, Ho EK, Vasilescu ER, et al. Anti-CD25 treatment and FOXP3-positive regulatory T cells in heart transplantation. Transpl Immunol. 2007; 18(1):13. [PubMed: 17584597]

113. Watanabe N, Wang YH, Lee HK, Ito T, Cao W, Liu YJ. Hassall's corpuscles instruct dendritic cells to induce CD4+CD25+ regulatory T cells in human thymus. Nature. 2005; 436(7054):1181. [PubMed: 16121185]

114. Yamazaki S, Iyoda T, Tarbell K, et al. Direct expansion of functional CD25+ CD4+ regulatory T cells by antigen-processing dendritic cells. J Exp Med. 2003; 198(2):235. [PubMed: 12874257]

115. Wakkach A, Fournier N, Brun V, Breittmayer JP, Cottrez F, Groux H. Characterization of dendritic cells that induce tolerance and T regulatory 1 cell differentiation in vivo. Immunity. 2003; 18(5):605. [PubMed: 12753738]

116. Mahnke K, Qian Y, Knop J, Enk AH. Induction of CD4+/CD25+ regulatory T cells by targeting of antigens to immature dendritic cells. Blood. 2003; 101(12):4862. [PubMed: 12543858]

117. Wu L, Shortman K. Heterogeneity of thymic dendritic cells. Semin Immunol. 2005; 17(4):304. [PubMed: 15946853]

118. Ardavin C, Wu L, Li CL, Shortman K. Thymic dendritic cells and T cells develop simultaneously in the thymus from a common precursor population. Nature. 1993; 362:761. [PubMed: 8469288]

Transplantation. Author manuscript; available in PMC 2011 September 15. 
119. Donskoy E, Goldschneider I. Two developmentally distinct populations of dendritic cells inhabit the adult mouse thymus: demonstration by differential importation of hematogenous precursors under steady state conditions. J Immunol. 2003; 170(7):3514. [PubMed: 12646612]

120. Goldschneider I, Cone RE. A central role for peripheral dendritic cells in the induction of acquired thymic tolerance. Trends Immunol. 2003; 24(2):77. [PubMed: 12547504]

121. Belz GT, Behrens GM, Smith CM, et al. The CD8alpha(+) dendritic cell is responsible for inducing peripheral self-tolerance to tissue-associated antigens. J Exp Med. 2002; 196(8):1099. [PubMed: 12391021]

122. Grohmann U, Bianchi R, Orabona C, et al. Functional plasticity of dendritic cell subsets as mediated by CD40 versus B7 activation. J Immunol. 2003; 171(5):2581. [PubMed: 12928409]

123. Roncarolo MG, Levings MK, Traversari C. Differentiation of T regulatory cells by immature dendritic cells. Journal of Experimental Medicine. 2001; 193(2):F5. [PubMed: 11208869]

124. DePaz HA, Oluwole OO, Adeyeri AO, et al. Immature rat myeloid dendritic cells generated in low-dose granulocyte macrophage-colony stimulating factor prolong donor-specific rat cardiac allograft survival. Transplantation. 2003; 75(4):521. [PubMed: 12605121]

125. Kitani A, Chua K, Nakamura K, Strober W. Activated self-MHC-reactive T cells have the cytokine phenotype of Th3/T regulatory cell 1 T cells. J Immunol. 2000; 165(2):691. [PubMed: 10878341]

126. Dieckmann D, Bruett CH, Ploettner H, Lutz MB, Schuler G. Human CD4(+)CD25(+) regulatory, contact-dependent $\mathrm{T}$ cells induce interleukin 10-producing, contact-independent type 1-like regulatory T cells [corrected]. J Exp Med. 2002; 196(2):247. [PubMed: 12119349]

127. Liu Z, Tugulea S, Cortesini R, Suciu-Foca N. Specific suppression of T helper alloreactivity by allo-MHC class I-restricted CD8+CD28-T cells. Int Immunol. 1998; 10(6):775. [PubMed: 9678758]

128. Watanabe N, Hanabuchi S, Soumelis V, et al. Human thymic stromal lymphopoietin promotes dendritic cell-mediated CD4+ T cell homeostatic expansion. Nat Immunol. 2004; 5(4):426. [PubMed: 14991051]

129. Liu YJ. A unified theory of central tolerance in the thymus. Trends Immunol. 2006; 27(5):215. [PubMed: 16580260]

130. Campbell JJ, Pan J, Butcher EC. Cutting edge: developmental switches in chemokine responses during T cell maturation. J Immunol. 1999; 163(5):2353. [PubMed: 10452965]

131. Lieberam I, Forster I. The murine beta-chemokine TARC is expressed by subsets of dendritic cells and attracts primed CD4+ T cells. Eur J Immunol. 1999; 29(9):2684. [PubMed: 10508243]

132. Alferink J, Lieberam I, Reindl W, et al. Compartmentalized production of CCL17 in vivo: strong inducibility in peripheral dendritic cells contrasts selective absence from the spleen. J Exp Med. 2003; 197(5):585. [PubMed: 12615900]

133. Chantry D, Romagnani P, Raport CJ, et al. Macrophage-derived chemokine is localized to thymic medullary epithelial cells and is a chemoattractant for CD3(+), CD4(+), CD8(low) thymocytes. Blood. 1999; 94(6):1890. [PubMed: 10477717]

134. Annunziato F, Romagnani P, Cosmi L, et al. Macrophage-derived chemokine and EBI1-ligand chemokine attract human thymocytes in different stage of development and are produced by distinct subsets of medullary epithelial cells: possible implications for negative selection. J Immunol. 2000; 165(1):238. [PubMed: 10861057]

135. Kumanogoh A, Wang X, Lee I, et al. Increased T cell autoreactivity in the absence of CD40CD40 ligand interactions: a role of CD40 in regulatory T cell development. J Immunol. 2001; 166(1):353. [PubMed: 11123312]

136. Salomon B, Lenschow DJ, Rhee L, et al. B7/CD28 costimulation is essential for the homeostasis of the CD4+CD25+ immunoregulatory T cells that control autoimmune diabetes. Immunity. 2000; 12(4):431. [PubMed: 10795741]

137. Serra P, Amrani A, Yamanouchi J, et al. CD40 ligation releases immature dendritic cells from the control of regulatory CD4+CD25+ T cells. Immunity. 2003; 19(6):877. [PubMed: 14670304]

138. Thorstenson KM, Khoruts A. Generation of anergic and potentially immunoregulatory $\mathrm{CD} 25+\mathrm{CD} 4 \mathrm{~T}$ cells in vivo after induction of peripheral tolerance with intravenous or oral antigen. Journal of Immunology. 2001; 167(1):188.

Transplantation. Author manuscript; available in PMC 2011 September 15. 
139. Chen W, Jin W, Hardegen N, et al. Conversion of peripheral CD4+CD25-naive T cells to CD4+CD25+ regulatory T cells by TGF-beta induction of transcription factor Foxp3. J Exp Med. 2003; 198(12):1875. [PubMed: 14676299]

140. Kretschmer K, Apostolou I, Hawiger D, Khazaie K, Nussenzweig MC, von Boehmer H. Inducing and expanding regulatory $\mathrm{T}$ cell populations by foreign antigen. Nat Immunol. 2005; 6(12):1219. [PubMed: 16244650]

141. Kawai T, Cosimi AB, Spitzer TR, et al. HLA-mismatched renal transplantation without maintenance immunosuppression. N.Engl.J.Med. 2008; 358(4):353. [PubMed: 18216355]

142. Gopinathan R, DePaz HA, Oluwole OO, et al. Role of reentry of in vivo alloMHC peptideactivated $\mathrm{T}$ cells into the adult thymus in acquired systemic tolerance. Transplantation. 2001; 72(9):1533. [PubMed: 11707742]

143. Oluwole OO, DePaz HA, Adeyeri A, Jin MX, Hardy MA, Oluwole SF. Role of CD41CD251 regulatory $\mathrm{T}$ cells from naive host thymus in the induction of acquired transplant tolerance by immunization with allo-major histocompatibility complex peptide. Transplantation. 2003; 75(8): 1136. [PubMed: 12717192]

144. Gleit ZL, Fuchimoto Y, Yamada K, et al. Variable relationship between chimerism and tolerance following hematopoietic cell transplantation without myelosuppressive conditioning in miniature swine. Transplantation. 2002; 74(11):1535. [PubMed: 12490786]

145. Horner BM, Cina RA, Wikiel KJ, et al. Predictors of organ allograft tolerance following hematopoietic cell transplantation. Am J Transplant. 2006; 6(12):2894. [PubMed: 17294522]

146. Gianello PR, Lorf T, Yamada K, et al. Induction of tolerance to renal allografts across singlehaplotype MHC disparities in miniature swine. Transplantation. 1995; 59:884. [PubMed: 7701585]

147. Wu A, Yamada K, Baron C, et al. Detection of regulatory cells as an assay for allograft tolerance in miniature swine. J Heart Lung Transplant. 2004; 23(2):210. [PubMed: 14761769]

148. Ierino FL, Yamada K, Hatch T, Sachs DH. Preliminary in vitro evidence for regulatory cells in a miniature swine renal allograft model. Transplant Proc. 1997; 29(1-2):1165. [PubMed: 9123255]

149. Okumi M, Fishbein JM, Griesemer AD, et al. Role of persistence of antigen and indirect recognition in the maintenance of tolerance to renal allografts. Transplantation. 2008; 85(2):270. [PubMed: 18212633]

150. Utsugi R, Lee RS, Barth RN, Kitamura H, Sachs DH, Yamada K. Mechanisms of tacrolimus induced tolerance to fully MHC-mismatched renal allografts in miniature swine: Donor antigen specific regulatory mechanisms. Transplantation. 2000; 69:S124.

151. Griesemer AD, Lamattina JC, Okumi M, et al. Linked suppression across an MHC-mismatched barrier in a miniature swine kidney transplantation model. J Immunol. 2008; 181(6):4027. [PubMed: 18768858]

152. Yamada K, Gianello PR, Ierino FL, et al. Role of the thymus in transplantation tolerance in miniature swine. I. Requirement of the thymus for rapid and stable induction of tolerance to class I-mismatched renal allografts. J Exp Med. 1997; 186(4):497. [PubMed: 9254648]

153. Yamada K, Gianello PR, Ierino FL, et al. Role of the thymus in transplantation tolerance in miniature swine - II. Effect of steroids and age on the induction of tolerance to class I mismatched renal allografts. Transplantation. 1999; 67(3):458.

154. Siemionow M, Izycki D, Ozer K, Ozmen S, Klimczak A. Role of thymus in operational tolerance induction in limb allograft transplant model. Transplantation. 2006; 81(11):1568. [PubMed: 16770246]

155. Onodera K, Volk HD, Ritter T, Kupiec-Weglinski JW. Thymus requirement and antigen dependency in the "infectious" tolerance pathway in transplant recipients. Journal of Immunology. 1998; 160(12):5765.

156. Garrovillo M, Ali A, DePaz HA, et al. Induction of transplant tolerance with immunodominant allopeptide-pulsed host lymphoid and myeloid dendritic cells. Am J Transplant. 2001; 1(2):129. [PubMed: 12099360]

157. Sayegh MH, Perrico N, Imberti O, Hancock WW, Carpenter CB, Remuzzi G. Thymic recognition of class II major histocompatibility complex allopeptides induces donor-specific unresponsiveness to renal allografts. Transplantation. 1993; 56:461. [PubMed: 7689263] 
158. Chowdhury NC, Murphy B, Sayegh MH, et al. Acquired systemic tolerance to rat cardiac allografts induced by intrathymic inoculation of synthetic polymorphic MHC class I allopeptides. Transplantation. 1996; 62:1878. [PubMed: 8990380]

159. Oluwole SF, Chowdhury NC, Ingram M, Garrovillo M, Jin MX, Agrawal S. Mechanism of acquired thymic tolerance induced by a single major histocompatibility complex class I peptide with the dominant epitope: differential analysis of regulatory cytokines in the lymphoid and intragraft compartments. Transplantation. 1999; 68(3):418. [PubMed: 10459547]

160. Oluwole SF, Chowdhury NC, Fawwaz RA. Induction of donor-specific unresponsiveness to rat cardiac allografts by intrathymic injection of UV-B-irradiated donor spleen cells. Transplantation. 1993; 55(6):1389. [PubMed: 8516824]

161. Vagefi PA, Ierino FL, Gianello PR, et al. Role of the thymus in transplantation tolerance in miniature Swine: IV. The thymus is required during the induction phase, but not the maintenance phase, of renal allograft tolerance. Transplantation. 2004; 77(7):979. [PubMed: 15087757]

162. Sho M, Kishimoto K, Harada H, et al. Requirements for induction and maintenance of peripheral tolerance in stringent allograft models. Proceedings of the National Academy of Sciences. 2005; 102(37):13230.

163. Zhao Y, Rodriguez-Barbosa JI, Swenson K, Zhao G, Arn JS, Sykes M. Highly disparate xenogeneic skin graft tolerance induction by fetal pig thymus in thymectomized mice: Conditioning requirements and the role of coimplantation of fetal pig liver. Transplantation. 2001; 72(10):1608. [PubMed: 11726819]

164. Zhao Y, Rodriguez-Barbosa JI, Swenson K, et al. The induction of specific pig skin graft tolerance by grafting with neonatal pig thymus in thymectomized mice. Transplantation. 2000; 69(7):1447. [PubMed: 10798769]

165. Nikolic B, Gardner JP, Scadden DT, Arn JS, Sachs DH, Sykes M. Normal development in porcine thymus grafts and specific tolerance of human T cells to porcine donor MHC. J Immunol. 1999; 162(6):3402. [PubMed: 10092795]

166. Zhao Y, Sergio JJ, Swenson K, Arn JS, Sachs DH, Sykes M. Positive and negative selection of functional mouse CD4 cells by porcine MHC in pig thymus grafts. Journal of Immunology. 1997; 159:2100.

167. Khan A, Sergio JJ, Zhao Y, Pearson DA, Sachs DH, Sykes M. Discordant xenogeneic neonatal thymic transplantation can induce donor-specific tolerance. Transplantation. 1997; 63:124. [PubMed: 9000673]

168. Lee LA, Gritsch HA, Sergio JJ, et al. Specific tolerance across a discordant xenogeneic transplantation barrier. Proceedings of the National Academy of Sciences of the United States of America. 1994; 91:10864. [PubMed: 7971974]

169. Zhao Y, Swenson K, Sergio JJ, Arn JS, Sachs DH, Sykes M. Skin graft tolerance across a discordant xenogeneic barrier. Nature Medicine. 1996; 2:1211.

170. Yamada K, Shimizu A, Ierino FL, et al. Thymic transplantation in miniature swine - I. Development and function of the "thymokidney". Transplantation. 1999; 68(11):1684. [PubMed: 10609944]

171. Yamada K, Shimizu A, Utsugi R, et al. Thymic transplantation in miniature swine. II. Induction of tolerance by transplantation of composite thymokidneys to thymectomized recipients. $\mathbf{J}$ Immunol. 2000; 164(6):3079. [PubMed: 10706697]

172. Yamada K, Vagefi PA, Utsugi R, et al. Thymic transplantation in miniature swine: III. Induction of tolerance by transplantation of composite thymokidneys across fully major histocompatibility complex-mismatched barriers. Transplantation. 2003; 76(3):530. [PubMed: 12923439]

173. Kamano C, Vagefi PA, Kumagai N, et al. Vascularized thymic lobe transplantation in miniature swine: thymopoiesis and tolerance induction across fully MHC-mismatched barriers. Proc Natl Acad Sci U S A. 2004; 101(11):3827. [PubMed: 15007168]

174. LaMattina JC, Kumagai N, Barth RN, et al. Vascularized thymic lobe transplantation in miniature swine: I. Vascularized thymic lobe allografts support thymopoiesis. Transplantation. 2002; 73(5): 826. [PubMed: 11907438] 
175. Nobori S, Samelson-Jones E, Shimizu A, et al. Long-term acceptance of fully allogeneic cardiac grafts by cotransplantation of vascularized thymus in miniature swine. Transplantation. 2006; 81(1):26. [PubMed: 16421473]

176. Nobori S, Shimizu A, Okumi M, et al. Thymic rejuvenation and the induction of tolerance by adult thymic grafts. Proc Natl Acad Sci U S A. 2006; 103(50):19081. [PubMed: 17148614]

177. Dorshkind K, Montecino-Rodriguez E, Signer RA. The ageing immune system: is it ever too old to become young again? Nat Rev Immunol. 2009; 9(1):57. [PubMed: 19104499]

178. Legrand N, Dontje W, van Lent AU, Spits H, Blom B. Human thymus regeneration and T cell reconstitution. Semin Immunol. 2007; 19(5):280. [PubMed: 17997107]

179. Hince M, Sakkal S, Vlahos K, Dudakov J, Boyd R, Chidgey A. The role of sex steroids and gonadectomy in the control of thymic involution. Cell Immunol. 2008; 252(1-2):122. [PubMed: 18294626]

180. Goldstein, AL.; Garaci, E.; New York Academy of Sciences. Thymosins in health and disease : first international conference; Malden, MA: Blackwell Pub. on behalf of the New York Academy of Sciences; 2007.

181. Zatz MM, Goldstein AL. Thymosins, lymphokines, and the immunology of aging. Gerontology. 1985; 31(4):263. [PubMed: 2414157]

182. Hirokawa K, McClure JE, Goldstein AL. Age-related changes in localization of thymosin in the human thymus. Thymus. 1982; 4(1):19. [PubMed: 7036424]

183. Markert ML, Devlin BH, Chinn IK, McCarthy EA. Thymus transplantation in complete DiGeorge anomaly. Immunol Res. 2008

184. Markert ML, Devlin BH, Alexieff MJ, et al. Review of 54 patients with complete DiGeorge anomaly enrolled in protocols for thymus transplantation: outcome of 44 consecutive transplants. Blood. 2007; 109(10):4539. [PubMed: 17284531]

185. Markert ML, Sarzotti M, Ozaki DA, et al. Thymus transplantation in complete DiGeorge syndrome: immunologic and safety evaluations in 12 patients. Blood. 2003; 102(3):1121. [PubMed: 12702512]

186. Chinn IK, Devlin BH, Li YJ, Markert ML. Long-term tolerance to allogeneic thymus transplants in complete DiGeorge anomaly. Clin Immunol. 2008; 126(3):277. [PubMed: 18155964]

187. Barth R, Yamamoto S, LaMattina JC, et al. Xenogeneic thymokidney and thymic tissue transplantation in a pig-to-baboon model: I. Evidence for pig-specific T cell unresponsiveness. Transplantation. 2003; 75

188. Yamada K, Yazawa K, Shimizu A, et al. Marked prolongation of porcine renal xenograft survival in baboons through the use of alpha1,3-galactosyltransferase gene-knockout donors and the cotransplantation of vascularized thymic tissue. Nat Med. 2005; 11(1):32. [PubMed: 15619627]

189. Calne R, Friend P, Moffatt S, et al. Prope tolerance, perioperative campath $1 \mathrm{H}$, and low-dose cyclosporin monotherapy in renal allograft recipients. Lancet. 1998; 351(9117):1701. [PubMed: 9734890]

190. Larsen CP, Pearson TC, Adams AB, et al. Rational development of LEA29Y (belatacept), a highaffinity variant of CTLA4-Ig with potent immunosuppressive properties. Am J Transplant. 2005; 5(3):443. [PubMed: 15707398]

191. Vincenti F, Larsen C, Durrbach A, et al. Costimulation blockade with belatacept in renal transplantation. N Engl J Med. 2005; 353(8):770. [PubMed: 16120857]

192. Abstract presented at ESOT mtg in Paris 8/30-9/3

193. Monaco AP, Wood ML. Studies on heterologous antilymphocyte serum in mice. VII. Optimal cellular antigen for induction of immunologic tolerance with antilymphocyte serum. Transplant Proc. 1970; 2(4):489. [PubMed: 4939696]

194. Wood ML, Monaco AP, Gozzo JJ, Liegeois A. Use of homozygous allogeneic bone marrow for induction of tolerance with antilymphocyte serum: dose and timing. Transplant Proc. 1971; 3(1): 676. [PubMed: 4398508]

195. Panijayanond P, Monaco AP. Enhancement of pancreatic islet allograft survival with ALS and donor bone marrow. Surg Forum. 1974; 25(0):379. [PubMed: 4216093] 
196. Hale DA, Gottschalk R, Umemura A, Maki T, Monaco AP. Immunologic mechanisms in tolerance produced in mice with nonradiation-based lymphoablation and donor-specific bone marrow. Transplantation. 2002; 74(4):477. [PubMed: 12352905]

197. Hartner WC, Markees TG, De Fazio SR, et al. The effect of antilymphocyte serum, fractionated donor bone marrow, and cyclosporine on renal allograft survival in mongrel dogs.

Transplantation. 1991; 52:784. [PubMed: 1835194]

198. Thomas JM, Neville DM, Contreras JL, et al. Preclinical studies of allograft tolerance in rhesus monkeys - A novel anti-CD3-immunotoxin given peritransplant with donor bone marrow induces operational tolerance to kidney allografts. Transplantation. 1997; 64:124. [PubMed: 9233712]

199. Monaco AP, Clark AW, Wood ML, Sahyoun AI, Codish SD, Brown RW. Possible active enhancement of a human cadaver renal allograft with antilymphocyte serum (ALS) and donor bone marrow: case report of an initial attempt. Surgery. 1976; 79(4):384. [PubMed: 769219]

200. Barber WH, Mankin JA, Laskow DA, et al. Long-term results of a controlled prospective study with transfusion of donor-specific bone marrow in 57 cadaveric renal allograft recipients. Transplantation. 1991; 51:70. [PubMed: 1987708]

201. Ciancio G, Burke GW, Moon J, et al. Donor bone marrow infusion in deceased and living donor renal transplantation. Yonsei Med J. 2004; 45(6):998. [PubMed: 15627290]

202. Monaco AP. Prospects and strategies for clinical tolerance. Transplant Proc. 2004; 36(1):227. [PubMed: 15013353]

203. Buhler LH, Spitzer TR, Sykes M, et al. Induction of kidney allograft tolerance after transient lymphohematopoietic chimerism in patients with multiple myeloma and endstage renal disease. Transplantation. 2002; 74(10):1405. [PubMed: 12451240]

204. Millan MT, Shizuru JA, Hoffmann P, et al. Mixed chimerism and immunosuppressive drug withdrawal after HLA-mismatched kidney and hematopoietic progenitor transplantation. Transplantation. 2002; 73(9):1386. [PubMed: 12023614]

205. Strober S, Lowsky RJ, Shizuru JA, Scandling JD, Millan MT. Approaches to transplantation tolerance in humans. Transplantation. 2004; 77(6):932. [PubMed: 15077041]

206. Scandling JD, Busque S, Dejbakhsh-Jones S, et al. Tolerance and chimerism after renal and hematopoietic-cell transplantation. N Engl J Med. 2008; 358(4):362. [PubMed: 18216356]

207. Fletcher AL, Lowen TE, Sakkal S, et al. Ablation and regeneration of tolerance-inducing medullary thymic epithelial cells after cyclosporine, cyclophosphamide, and dexamethasone treatment. J Immunol. 2009; 183(2):823. [PubMed: 19564346]

208. Baan CC, van der Mast BJ, Klepper M, et al. Differential effect of calcineurin inhibitors, antiCD25 antibodies and rapamycin on the induction of FOXP3 in human T cells. Transplantation. 2005; 80(1):110. [PubMed: 16003241]

209. Zeiser R, Nguyen VH, Beilhack A, et al. Inhibition of CD4+CD25+ regulatory T-cell function by calcineurin-dependent interleukin-2 production. Blood. 2006; 108(1):390. [PubMed: 16522809]

210. Strauss L, Czystowska M, Szajnik M, Mandapathil M, Whiteside TL. Differential responses of human regulatory T cells (Treg) and effector T cells to rapamycin. PLoS One. 2009; 4(6):e5994. [PubMed: 19543393]

211. Liu C, Noorchashm H, Sutter JA, et al. B lymphocyte-directed immunotherapy promotes longterm islet allograft survival in nonhuman primates. Nat Med. 2007; 13(11):1295. [PubMed: 17965721] 


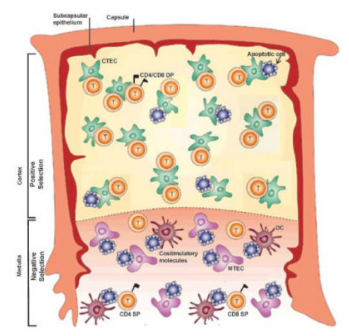

Figure 1.

Positive and negative selection in the thymus. Thymocytes enter the cortex and undergo $\mathrm{T}$ cell receptor (TCR) gene rearrangement and display both CD4 and CD8. These cells interact with cortical thymic epithelial cells (CTEC) and undergo apoptosis unless they receive a survival signal generated via TCR/self-peptide-MHC interaction. Positively selected thymocytes progress to single-positive CD4 or CD8 cells and enter the medulla. Highavidity TCR/self-peptide-MHC ligation in the presence of medullary thymic epithelial cell (MTEC) or dendritic cell (DC) co-stimulatory molecules in the medulla lead to negative selection of self-reactive thymocytes. (Modified with permission from Palmer E. Negative selection--clearing out the bad apples from the T-cell repertoire. Nat Rev Immunol 2003; 3 (5): 383.$)$ 